Het belangrijkste essay in Naked Authority is ongetwijfeld het opstel dat de auteur aan het overbekende schilderij van Manet, Le déjeuner sur l'herbe wijdt. Zij stelt dat het schilderij geenszins een allegorie betekent, maar veeleer de crisis van de integratie van het vrouwelijke naakt in de schilderkunst, omdat hier verwarring heerst tussen het stilistische karakter van het vrouwelijke naakt en de blote vitgeklede anwwezigheid die door geen enkele betekeniscontext zou gerechtvaardigd zijn. Juist deze betekenis van het werk zou later tot zoveel parodieèn hebben aanleiding gegeven. Is een andere interpretatie mogelijk ? Kan deze naakte vrouw niet het zinnebeeld zijn van wat het intellectueel discussierend stedelijke tweetal evoceert? Zouden deze mannen het niet over de Natuur hebben? Ook zulk een interpretatie sluit cen mogelijke parodie niet uit.

Dit goed gellustreerde boek van Marcia Pointon kan als een voorbeeld gelden van een hedendangse kunst- en cultuurgeschiedenis die aan cen louter esthetiserende benadering voorbij gaat. De auteur wil weloverwogen studies in een hedendaagse perspectief situeren; ze maakt van de conceptualisaties uit de nieuwste verworvenheden en ideeen van de menswetenschappen gebruik en weet dat de de-constructionistische kritiek $v$ an de historisch gegroeide thetoriek in de schilderkunst andere gezichtspunten kan bieden. Naked Authority is daarom een boek dat de discussies kan levendig houden.

Jacques DE VISSCHER

\title{
DECONSTRUCTIE EN HET NIEUWE HOLISME
}

Jean Paul Van Bendegem, Inleiding tot de moderne logica en wetenschapsfilosofie : een terreinverkenning, Brussel, VUBPress, 1991, 240 blz, 880 Bfr., ISBN 9070289792.

Een grootschalige terreinverkenning is dit boek vast en zeker geworden. In vier kwantitatief gelijkwaardige delen (ca. zestig blz.) slaagt de auteur erin een boeiend overzicht te presenteren van de actuele stand van het onderzoek op het domein van de moderne geformaliseerde logica, de argumentatieleer, de wetenschapsfilosofie en de grenzen van artificięle taalsystemen (wiskunde, geformaliseerde logica en informatica). Het eerste deel bevat een beknopt overzicht van de (klassieke) propositielogica, de deelsystemen van de propositielogica (meerwaardige logica's, inturtionisme), de 'uitbreidingen van de propositielogica (de predicatenlogica van de eerste orde, de alethische, deontische, epistemische, relevante en paraconsistente logica's) en tenslotte de modale predicatenlogica's. In het tweede deel wordt de geformaliseerde logica vanuit twee hoeken onder vuur genomen. Na een korte overgangsparagraaf over de dialoogformulering van de formele logica (Lorenzen) behandelt de auteur eerst de normatieve kritiek op de geformaliseerde logica (de argumentatietheorietn : A. Naess, E. Barth en E.C.W. Krabbe, Ch. Perelman, St. Toulmin, de informele logica en de 'Critical Thinking Movement'). Vanuit descriptieve hoek komt de kritiek in de vorm van een aantal experimenten, die moeten santonen dat 
wij dikwijls niet redeneren volgens de wetten van de geformaliseerde logica. Het eerste deel wordt dan afgesloten met een recupererende analyse van het begrip 'rationaliteit' die ook ruinte biedt voor (de verklaring van) denkfouten.

Dezelfde indeling normatieffescriptief is ook terug te vinden in het derde deel. Hierin komen de belangrijkste hedendaagse wetenschapsfilosofen aan bod. E. Mach, B. Russell, L. Wittgenstein, de Wiener Kreis, C. Glymourzijn, K. Popper en J. Sneed zijn voorstanders van een formeel-normatieve benadering van de wetenschap. De waarschijnlijkheidsberekening biedt een alternatieve normatieve aanpak van het verschijnsel wetenschap. Th. Kuhn, I. Lakatos, P. Feyerabend, de school van Edinburgh en L. Laudan beschrijven het fenomeen wetenschap. De snelle ontwikkeling van de computer biedt perspectieven inzake het simuleren van het wetenschappelijke denken.

Het laatste deel tenslotte bevat een aantal eerder technische meta-theorieën met betrekking tot de logica en de wiskunde. Hieronder ressorteren onder meer : het probleem van de beslisbaarheid van de logica (meer bepaald de predicatenlogica van de eerste orde); de paradoxen van Zeno en de bespreking van de vraag of een machine kan denken.

De encyclopedische waarde van dit nieuwe handboek staat buiten twijfel. Van Bendegem is erin geslaagd de verschillende deelgebieden van de wetenschap in een boeiende en vlotte stijl samen te vatten. Een aanrader voor al wie wil kennis maken met de vaak onbekende (en onbeminde) wetenschappen zoals logica, wiskunde, informatica en wetenschapsleer. De auteur reikt bovendien menigvuldige referenties aan voor diepgaander studie en elk deel wordt afgesloten met een geselecteerde bibliografie.

Toch wil dit boek meer bieden dan een encyclopedische terreinverkenning. De auteur neemt zich voor de verbanden aan te tonen tussen de verschillende wetenschappelijke disciplines. Binnen de besproken wetenschappen blijkt er bovendien eenzelfde evolutie aan de gang te zijn. De rode draad die doorheen dit boek loopt zou men als volgt kunnen samenvatten. De moderne geformaliseerde logica doet zich voor als een normatieve en formele studie die het dwingend karakter van geldige redeneringen blootlegt. Een aantal experimenten, zoals het kaarten-experiment van $W$ ason, toont echter aan dat de mens niet altijd redeneert zoals de logica voorschrijft, omdat hij niet neutraal (dat wil zeggen louter deductief) omspringt met de gegevens (de premissen) die hem voorgeschoteld worden. Intuitief laat hij het positieve prevaleren boven het negatieve, het eerdere boven het latere en het concrete boven het abstracte. Hij redeneert dan on-logisch omdat de geformaliseerde logica een aantal mentale processen volledig over het hoofd ziet; de geformaliseerde logica is te abstract. Wat door een aantal experimenten wordt aangetoond wordt in de argumentatietheorie gefundeerd. Als normatieve studie zou de argumentatieleer een alternatief kunnen bieden voor de geformaliseerde logica (blz. 117).

Ook in de wetenschapsleer maakt de auteur - zij het met enige schroom - het onderscheid tussen een normatieve en een descriptieve aanpak van het probleem. De normatieve wetenschapsleer verantwoordt de wetenschap terwijl de descriptieve aanpak laat zien hoe de wetenschap aan haar resultaten komt. Het hoeft dus niet te verwonderen dat de geformaliseerde logica een belangrijke rol speelt bij de opbouw van een normatieve wetenschapsfilosofie. In de wetenschapsleer ontwaart de auteur een verschuiving van de normatieve aanpak naar de descriptieve aanpak van de wetenschap; dat geldt zelfs voor de wiskunde : de vraag naar de grondslagen van de wiskunde slaat om naar de vraag hoe 
wiskundigen omgaan met hun wetenschapsbeoefening. Het gebruik van steeds krachtigere computers lijkt daarbij van zeer groot belang te zijn, alhoewel, computers denken niet. Hoe snel zij ook de bewerkingen kunnen uitvoeren, toch blijven zij ook in de tijd beperkt en kunnen zij nooit het menselijke denken vervangen (J. Lucas, J. Searle, H.L. Dreyfus).

Hoewel bij elke herlezing van het boek nieuwe verbanden en combinaties verschijnen (dit alleen maakt het boek reeds de moeite waard) kan men zich toch niet van de indruk ontdoen dat de auteur een aantal van die verbanden zelf in de hand heeft gewerkt. Heel het boek van Van Bendegem gaat gebukt onder een zwaar dualisme met aan de ene kant het normatieve en aan de andere kant het descriptieve. De norm (de geformaliseerde logica) wordt getoetst aan de feiten (een aantal experimenten). Deze confrontatie resulteert in cen discrepantie. Ten overstaan hiervan kan men volgens Van Bendegem (blz. 71) twee houdingen aannemen : ofwel moeten de feiten zich aanpassen aan de norm (moet de logica de mensen leren correct redeneren ?) ofwel past men de norm aan (in de vorm van een argumentatieleer of een nieuwe definitie van rationaliteit). De auteur kiest voor de tweede opvatting. Tegen deze stellingname kunnen uiteraard principiele bezwaren worden aangevoerd (moeten de regels van het voetbalspel worden aangepast zodat scheidsrechters geen gele of rode kaarten meer dienen uit te delen ?). Bovendien stelt de auteur de tegenstelling tussen de geformaliseerde logica en het feitelijke denken van de mens in een verkeerd daglicht. De auteur kiest - en dat is zijn volste recht - voor de modeme geformaliseerde logica, maar hij moet toegeven dat de corspronkelijke bedoeling van deze logica erin bestond "de grondslagen van de wiskunde op te lossen" (blz. 17). Hoeft het dan te verwonderen dat die logica soms ver staat van ons (veelal niet-deductief) redeneren ? Is de vraag "of de formele logica, zoals in deel I uiteengezet, niet fundamenteel verkeerd georiènteerd is" (blz. 73) wel een eerlijke vraag ? Bovendien presenteert de auteur de geformaliseerde logica op een manier die een aantal interessante verbanden met de natuurlijke taal onvoldoende aan bod laat komen : zo maakt hij geen duidelijk onderscheid tussen redenering (in de natuurlijke taal) en redeneringsvorm (in de symbolentaal van de logica); het probleem van het formaliseren (het omzetten van zinnen in de natuurlijke taal naar de symbolentaal) wordt slechts incidenteel (blz. 43) aangesneden; de problematiek van 'de adequate vorm' voor een zin of redenering komt onvoldoende aan bod, alsook de interpretatie van de zogenaamde 'paradoxen' en, daarmee samenhangend, de verklaring waarom logici steeds opnieuw op zoek zijn gegaan nasr nieuwe logica's. De auteur verwondert zich niet alleen over het feit dat de regels van het voetbalspel niet op andere sporten van toepassing zijn, maar kiest bovendien een formulering voor die regels die mogelijke gelijkenissen met andere sporten bemoeilijkt. De presentatie van de geformaliseerde logica is bovendien niet zeer consequent : bij de basissystemen (de propositielogica en de predicatenlogica van de eerste orde) is het vertrekpunt de natuurlijke deductie van het Fitch-type (een referentie naar het corspronkelijke werk van Fitch [F.B. Fitch, Symbolic Logic. An Introduction, New York, MacMillan, 1952] ontbreekt in de bibliografie); de semantiek en de axiomatiek komen later. De deelsystemen van de propositielogica vertrekken van de semantiek van het Hughes en Cresswell-type; de uitbreidingen van de propositielogica daarentegen vertrekken van de axiomatiek. Studenten en de geïnteresseerde leek, voor wie dit boek is bestemd (blz. 5), hebben alle baat bij een consequente aanpak. Een uniforme semantische presentatie van de geformaliseerde logica (bijvoorbeeld van het 
Hughes en Cresswell-type) ware wenselijk geweest. Hierdoor zou cen aantal hogerop aangestipte (gemiste) kansen aangegrepen kunnen worden (wat er precies fout loopt in het kaartenexperiment kan veel beter aan de hand van de matrix van de implicator worden uitgelegd dan aan de hand $v$ an de modus [ponendo] ponens-redenering) en zou aan het hele logica-bedrijf een degelijker filosofische basis gegeven kunnen worden

Jan Frans LINDEMANS

\section{NEDERLANDS-VLAAMSE FILOSOFIEDAG}

Erik Heijerman \& Paul Wouters (red.), Crisis van de rede? Perspectieven op cultuur. Assen/Maastricht. Van Gorcum, 1992, XII + 416 blz. Hfl. 43,50 ISBN 9023226607

Elk najaar komen Nederlandse en Vlaamse filosofen op een zaterdag in een of andere universiteit samen om te luisteren naar wat de collega's in hun vakgebied bezighoudt. Sommigen brengen een korte beschouwing die in hun werk een eerder zelfstandige plaats inneemt, anderen brengen een onderdeel uit hun onderzoeksprogramma, meestal voor een dissertatie of voor een boek in wording. In beginsel komen hier de jongeren aan bod en in het beste geval luisteren de reeds gevestigde wijsgeren naar hun jongere collega's. Zo'n filosofiedag betekent dan het ideale ontmoetingsmoment waarop men nieuwe gezichten ziet en vooral andere klanken hoort. Het succes van deze filosofiedagen wordt elk jaar groter.

In tegenstelling tot de traditie had de dertiende filosofiedag (26 oktober 1991) niet in een universiteit uit Noord of Zuid plaats, maar wel in de Internationale School voor Wijsbegeerte te Leusden (Nederland) en dit bij de gelegenheid van haar vijfenzeventigste verjaardag. Hiervan zijn nu de teksten gepubliceerd : een fraaie, ingenaaide uitgave die door de directeur van de school, Paul Wouters, en door een van zijn medewerkers, Erik Heijerman, wordt ingeleid. Zij rechtvaardigen het overkoepelende thema van de studiedag en komen tot de vaststelling : "zo er geen sprake is van een crisis van de rede, dan is er ten minste sprake van enige verwarring van de rede; en al zou het misschien overdreven zijn te spreken van een verwarring van de rede, dan is kennelijk wel te spreken van een verwarring van de filosofische rede" (blz. X). Moet dit ontmoedigend werken ? Wijsgeren laten zich hier niet door afschrikken, zij zien wel altijd nieuwe perspectieven of voelen zich door 'een dialektiek van de crisis' hoopvol gestemd. Exemplarisch hierin is de openingstoespraak van C.A. van Peursen, een van de gezaghebbende stemmen uit het na-oorlogse wijsgerig leven in Nederland. Hij onderkent het feit dat de traditionele filosofische rede is opengebroken, onder meer door de confrontatie met de niet-westerse beschavingen, maar juist dit feit heeft tot een positieve verruiming van de westerse rede aanleiding gegeven. Daarom heeft hij het over een vruchtbaar 'openbreken', dit wil zeggen "dat de rede 